\title{
Tributes private and public
}

We tend to separate Shakespeare from other authors; he appears timeless, and deserves to stand apart. But Shakespeare was, after all, a writer - a great writer, of course, but he was also an infant, adolescent, lover, husband, father, and man. Weren't his own life experiences as important to him as, say, Antony's or Bolingbroke's, or more so? Weren't his friendships as dear to him as Valentine's, his loves as unquenchable as Helena's, his losses as bitter as Hamlet's? Though a multitude of commentators and biographers have judged Shakespeare an unusually secretive person, wouldn't it be stranger still if events in his own life did not colour his works?

Every fiction writer's oeuvre constitutes an autobiography. Though it may not be linear, cannot be literal, might intentionally obfuscate or drift into fantasizing, it is notwithstanding true. It is truer than can be any biography written by a researcher-comelately, no matter how diligent, perceptive, and blunt. I have argued that Shakespeare's works are no exception, that his sonnets and plays are studded with local, topical, and personal allusions, many of them yet to be recovered. As I will suggest in this chapter, some of the most trenchant and revealing are the tributes he fashioned for those he mourned. Because they were written as 'private' memorials, that is, for a very small coterie among Shakespeare's auditors, they have remained completely opaque to commentators for centuries, and even now are difficult to detect and parse.

\section{Private memorials on stage}

With the writing of King John in 1596 (if not years before), William Shakespeare began a practice of inscribing into his texts tributes to deceased friends, family, and benefactors. The most conspicuous 
of these (if not to us then perhaps to his colleagues and some first auditors) was his play-length tribute to Marlowe. He also drew three portraits of Thom Nashe in Love's Labour's Lost, As You Like It, and Twelfth Night. Another, briefer memorial written for the deceased William Brooke, Tenth Baron Cobham and Lord Chamberlain, appears in Henry $V$.

Brooke is said to have taken umbrage at Shakespeare's adoption of the name of his famous predecessor, Sir John Oldcastle (d. 1417), for the misleader of Prince Hal in 1 Henry IV (1596). (See the discussion of the Oldcastle contretemps in 'Shakespeare's bad timing' in Longer notes' below.) In August 1596 Brooke succeeded Henry Carey as Lord Chamberlain; he briefly held the post until his death in March 1597, at which time Carey's son, George (1547-1603), attained the post. Perhaps because of lingering enmity between the Careys and Brookes, Shakespeare waited almost two years before Falstaff's death provided the appropriate vehicle. Shakespeare also framed his tribute in such a way that only Brooke's nearest family and friends would recognize it.

In Henry V 2.3 Bardolph, Pistol, and their Eastcheap brothersin-arms are preparing to join the King's expedition to France when Hostess brings word that Sir John Falstaff has died. On hearing this Bardolph declares, 'Would I were with him, wheresome're he is, either in heaven or in hell.' Hostess responds,

Nay, sure he's not in hell. He's in Arthur's bosom if ever man went to Arthur's bosom. A made a finer end, and went away an it had been any christom child. A parted ev'n just between twelve and one, ev'n at the turning o'th' tide - for after I saw him fumble with the sheets, and play with flowers, and smile upon his finger's end, I knew there was but one way. For his nose was as sharp as a pen, and a babbled of green fields. $(9-16)^{1}$

Hostess's speech has two thrusts. First, she assures us that, after a death as decorous as any innocent child's, Falstaff has been saved; his soul has flown directly to 'Arthur's bosom' - that is, Abraham's heavenly bosom. Given that Hostess is speaking on the eve of Henry's departure for France, 11 August 1415, Falstaff's is a remarkably early exemplar of a Protestant death and instantaneous salvation. Then again, Foxe and the Elizabethans admired the Lollard John Oldcastle as an archetypal Protestant. ${ }^{2}$ The second element of Hostess's speech is a three-part description of the moment of Falstaff's death. 
Hostess begins with (1) the hour of death, telling us that Falstaff 'parted ev'n just between twelve and one', that is, between midnight and 1 a.m. She also that noticed Falstaff died (2) 'ev'n at the turning o'th' tide'. This was the traditional hour of leave-taking, when ships left harbour and sailors said farewell to loved ones; it became proverbial for that final leave-taking, death. Non-sailors should understand that 'tide-turn' is not an instantaneous event; in the Thames the tide rose and fell almost imperceptibly in the half-hour before and after turn. ${ }^{3}$ This seeming lack of flow is known as 'slack tide'.

Finally, Hostess tells us that (3) Falstaff 'babbled of green fields' that is, he attempted to recite the Twenty-Third Psalm. The version in the Geneva Bible (1599) begins, 'The Lord is my shepherd, I shal not want. He maketh me to rest in grene pasture, $\&$ leadeth me by the still waters.'

So Falstaff died:

1. Between 12 midnight and 1a.m.

2. At the turning of the tide.

3. Having muttered the Twenty-Third Psalm.

I will demonstrate that these three details form a precise epitome of the death of William Brooke, whose forebear Oldcastle was sometime Falstaff.

We know from a letter of Rowland Whyte to Sir Robert Sydney that Brooke died on the night of 5-6 March; on Sunday 6 March Whyte wrote, 'About midnight my Lord Chamberlain [Brooke] died.' So both Falstaff and Brooke died (1) at the midnight hour.

The site of Brooke's death was his home at Blackfriars where the Fleet River entered the Thames. With modern oceanographic computer software it is possible to recover the time at which the tide in the Thames turned on the night of 5-6 March 1597. In fact, tideturn at London Bridge was 12.19 a.m. - that is, nineteen minutes after midnight 'ev'n just between twelve and one'. Like Falstaff, Brooke (1) died at the midnight hour as (2) the tide turned.

Hostess also reports that Falstaff mumbled the Twenty-Third Psalm. Elizabethans who followed the liturgical calendar in the Book of Common Prayer would read or recite all 150 Psalms over the course of each month. After years of repetition many could instantly recall the evening of the month prescribed for the beloved Twenty-Third Psalm. It was the fourth - except in March, when the 
Twenty-Third Psalm was prescribed for evening prayer on the fifth day of the month. ${ }^{4}$

So Falstaff and Brooke both died (1) at the midnight hour (2) at the turning of the tide, and (3) in association with the Twenty-Third Psalm.

Of course, these might be three coincidences. But is that likely? Particularly given the awkward association of Brooke with Oldcastle-Falstaff in 1 Henry IV?

A better question is: who among Shakespeare's auditors could have recognized these ephemeral connections between the deaths of Oldcastle-Falstaff and Brooke? Only those persons so close to Brooke that they would have attended his death.

Family members and intimate friends who were present in the death room would certainly have noted the hour of Brooke's passing. Some of them may have made the journey to his Blackfriars residence by water, and may have had to return home by the same route; they would have been mindful of the turning of the tide. And all those who were confessing Anglican Christians may well have joined in reciting that evening's devotions including the Twenty-Third Psalm. This is just the tiny coterie audience that Shakespeare wished to reach with his encomium for his late benefactor.

Hostess's insistence that Falstaff (and Brooke) made a fine end and flew to Abraham's bosom is Shakespeare's gentle memorial for his deceased Lord Chamberlain.

\section{How Henry Carey inspired Faulconbridge}

Emrys Jones liked to caution his doctoral candidates (myself included): 'We have Shakespeare's plays, but not his mind.' That was his way of discouraging extravagant speculation about Shakespeare's meanings (doubtless, Professor Jones would have been horrified by the title of this book). One of the questions raised during those tooshort tutorials in his rooms at New College concerned King John: was Shakespeare's play a rewrite of an anonymous (and not very good) play, The Troublesome Reign of King John (ca. 1589)? Or was The Troublesome Reign a rewrite of Shakespeare?

Though the former sequence is now widely accepted, in 1993 scholars were still divided. Early in the twentieth century Peter Alexander thought Shakespeare's the earlier; in his Arden Series 2 
edition (1963) Ernst Honigmann supported Alexander's theory. ${ }^{5}$ And twenty years later in Shakespeare's Influence on his Contemporaries Honigmann elaborated this mistaken idea. ${ }^{6}$ Formidable scholars queued on both sides of the question. ${ }^{7}$

More than a decade passed before Kenneth Muir finally unhorsed the scurrilous notion in $1977 .{ }^{8}$ Nowadays, the consensus rightly holds that The Troublesome Reign provided the template for Shakespeare's King John. But as late as the 1990s, the AlexanderHonigmann position had its adherents. Professor Jones also raised a corollary question: didn't it appear that Shakespeare's sole purpose in rewriting the earlier play was to create the heroic Bastard Faulconbridge?

In time I concluded that Shakespeare had created his King John and the character of the royal Bastard as a tribute to his recently deceased Lord Chamberlain and patron, royal bastard Henry Carey, who died on 23 July 1596. As well, I inferred that Constance's lament for her Arthur expressed the playwright's own grief at the death of Hamnet Shakespeare, buried a mere nineteen days later. As luck would have it, over lunch one summer Sunday I had occasion to offer my conclusion to Professor Jones. He took it aboard, but I've never been entirely sure he believed it.

In fact, Shakespeare wrote two memorials for Henry Carey, one in King John, a second in Hamlet. In the former play Shakespeare modelled the character of Philip Faulconbridge on Carey. Some resemblances are obvious: both were royal bastards, swashbuckling campaigners, heroic, resourceful, cynical, steadfast, and unshakably loyal. But Shakespeare's linkage of the two illegitimates runs much deeper; indeed, it may border on sedition.

Carey's claim to the English crown was every bit as good (and bad) as Elizabeth's. Born in 1533, Elizabeth had been declared a bastard by her father and Act of Parliament (1536). Carey was her senior (born ca. 1526) and male - either trait would have been sufficient to give him precedence in the royal succession had both their births been legitimated. Notwithstanding, Carey proved the Queen's unflaggingly loyal subject; he laboured tirelessly and heroically in Elizabeth's service in the northern wars, on her Privy Council, and as chief of her personal bodyguard during the Armada emergency of 1588. Like Shakespeare's Faulconbridge, who sought no honours beyond service, Carey (on his deathbed) refused Elizabeth's offer of an earldom. ${ }^{9}$ 
Carey was no fey courtier; contemporary accounts characterize him as frank, outspoken, bluff - in Sir Robert Naunton's phrase, 'He loved sword and buckler men'. ${ }^{10}$ Throughout her reign Elizabeth relied on Carey's capabilities - and loyalty - implicitly. She sent him north in 1568 to quell the intrigues festering about Mary Queen of Scots and numberless conspiracies among the northern earls and their Scots accomplices. Though Carey's troops were vastly outnumbered, he won a series of startling victories; the Queen wrote, 'you were by God appointed the instrument of my glory'. ${ }^{11}$ This was the stuff of legend.

By spring 1571, the northern marches were quieted. But Carey still pursued the renegade Earl of Northumberland - which led to a memorable episode. Carey 'used the threat of force to bring about the surrender of the castle [at Leith] but to no avail; the defenders hoped for succour from France while the king's party clamoured insistently for more money ... [finally] in May 1572 the Scots handed over Northumberland in return for $£ 2000 .{ }^{12}$ Commodity, indeed.

Carey's magic touch in the north made him indispensable to Elizabeth for the next fifteen years. Though the Queen appointed him to her Privy Council in 1577 and handed him the Chamberlain's wand in July 1585, Elizabeth repeatedly sent Carey north when danger threatened. His final sally was in 1587. As the Armada crisis loomed Carey was abruptly recalled in April 1588 to raise musters in Norfolk and Suffolk and to serve as chief of the Queen's personal bodyguard, which implies that Carey enjoyed the Queen's perfect trust. For this service Elizabeth presented him with the magnificent Hunsdon Onyx. Carey died on 23 July 1596 and was buried in Westminster Abbey on 12 August (one day after Hamnet Shakespeare) at the Queen's expense - a fitting tribute to the extraordinary career of a royal bastard. His heirs and friends erected a monument that is, even by Westminster standards, regal. ${ }^{13}$

The moment in Carey's life which most strikingly embodies the royalty of spirit with which Shakespeare endued his Faulconbridge was his final hour. Carey had long sought an earldom for himself and his heirs. Perhaps because of his (unspoken) claim to the crown Elizabeth denied him this advancement. It wasn't until Carey was dying that the Queen relented. Fuller reported that

When he [Carey] lay on his death-bed, the Queen gave him a gracious visit, causing his Patent for the said Earldom to be drawn, his Robes 
to be made, and both to be laid down upon his bed; but this Lord (who could dissemble neither well nor sick) 'Madam,' said he, 'seeing you counted me not worthy of this honour whilst I was living, I count myself unworthy of it now I am dying. ${ }^{14}$

If there is truth to this tale, Carey's words must have been whispered among his intimates and retainers - and more widely - within moments after they fell on the chastened ear of the Queen.

It is, I suggest, Henry Carey's fault that King John is considered Shakespeare's most unsatisfying play; its 'stage history in the twentieth century is a melancholy record of fewer and fewer productions'. ${ }^{15}$ Even the handful of scholars who have written at length about King John find themselves sorely pressed to appreciate (or defend) its curiously hollow structure and lack of a central hero-figure. ${ }^{16}$ Sigurd Burckhardt wrote: 'Even bardolaters have little good to say about the last two acts ... And I strongly suspect Shakespeare himself knew he was not bringing the thing off. ${ }^{17}$ The play's most admired Shakespearean creation is dismissed as a supernumerary: 'King John with Faulconbridge as hero is a play without form and void, signifying nothing. He is outside the structure of the play as he is outside it historically. ${ }^{18}$ But the fact is, Faulconbridge and Henry Carey were the heart and soul of the play.

Our principal dissatisfaction with King John comes in the final act when Prince Henry makes his sudden appearance and we find ourselves convinced that the wrong man (boy) possesses the throne. In 1962, William Matchett identified the root of our discontent:

The plot of King John is built around the question of who should be King of England and thus of what constitutes a 'right' to the throne. In the first act, three characters are shown to have particular claims to the crown. With the death of Arthur, the failure and eventual collapse of John and ... it would appear that the Bastard is being groomed to take over as rightful king. The final scenes, however, with their surprising introduction of a new claimant of unknown character and ability [Prince Henry], defeat this expectation. ${ }^{19}$

I believe that this disconcerting denouement is precisely the effect Shakespeare was driving for when he took up The Troublesome Reign and created the Bastard Faulconbridge to commemorate Henry Carey, that is, the wrong heir occupies the throne. This patent sedition has never been recognized by scholars. 


\section{Shakespeare's leap to the sixteenth century}

In those months immediately following Carey's death it would not have taken much to encourage the wiser sort among Shakespeare's audience to correlate his dashing Faulconbridge with the lategreat, larger-than-life Henry Carey. The character's royal bastardy, outspoken manner, heroism, and selfless honour could have been sufficient to establish the connection. But Shakespeare adopted two subtle strategies to tighten the links between Carey and the Bastard. First, through time-shift signals he jogged his auditors' focus from the thirteenth to the sixteenth century.

Time-shifts were a familiar tactic for delving into contemporary subjects which might be banned by the censors. One device which Shakespeare employed in King John is a reference to a French 'armado' (3.4.2). ${ }^{20}$ Shakespeare's loaded word, armado does not appear in The Troublesome Reign; it is also Spanish in form, armada being the French. When Shakespeare's French King Philip announces that his 'armado' has foundered some auditors could detect a link with the fate of Spanish King Philip's Armada of $1588 .{ }^{21}$ Henry Carey played a heroic role during that emergency just as the Bastard will emerge to lead the armies of King John.

Another of Shakespeare's time-shift signals - obscure to us but resonant with Elizabethans - appears in John's diction as he defies the papal legate, Pandulph:

What earthie name to Interrogatories

Can tast the free breath of a sacred King?

Thou canst not (Cardinall) devise a name

So slight, unworthy, and ridiculous

To charge me to an answere, as the Pope:

Tell him this tale, and from the mouth of England,

Adde thus much more, that no Italian Priest

Shall tythe or toll in our dominions:

But as we, under heaven, are supreme head,

So under him that great supremacy

Where we doe reigne, we will alone uphold

Without th'assistance of a mortall hand. (3.1.147-58)

In this speech Lily B. Campbell detects 'the voice of Elizabeth' speaking through John; ${ }^{22}$ her inference misses the mark. It is not Elizabeth speaking but her father, Henry VIII. A careful reading of 
Shakespeare's words reveals a precise epitome of Henry's attacks on the power of the papacy in England.

To begin, 'interrogatories' are legal questions, usually in writing, demanded of a witness or litigant. Thomas More notes in his Apology that it was common practice to question suspected heretics from a written list of interrogatories; many of the questions were cleverly designed to trip the interrogatee and/or entrap him in heresy. ${ }^{23}$ But it was also common for a secular or clerical court, when witnesses or litigants were distant, to send written interrogatories to be answered under oath in the presence of an officer. In 1533 the practice of sending interrogatories from Rome to England and vice versa was outlawed by the Act in Restraint of Appeals (24 Henry VIII, c. 12).

John's next lines ridicule the name 'Pope' and exchange it for 'Italian priest', a common epithet in Shakespeare's time. The Pope's title was officially denounced in the Ecclesiastical Licenses Act $(25$ Henry VIII, c. 21) of 1534, which makes repeated references to 'the Bishop of Rome, called the Pope'.

John next dismisses the Pope's power to 'tythe or toll in our dominions'. Tithing and tolling are distinct activities. In 1532, Act 23 Henry VIII, c. 20 placed a moratorium on the payment to the Pope of those tithes known as 'first fruits', that is, the first year's revenues of a newly appointed English bishop. This ban became permanent in 1534 under the Act Restraining the Payment of Annates (25 Henry VIII, c. 20). As to the Pope's power to 'toll' that is, to levy a tax upon the kingdom of England by exacting an annual tribute of $£ 200$ known as 'Peter's pence' - this facility was suppressed by the Ecclesiastical Licences Act.

Finally, we come to John's proclamation that 'we, under heaven, are supreme head' of the church in England. The words derive from the Act of Supremacy (26 Henry VIII, c. 1) of 1534, which finally made official the break with Rome: 'the King's Majesty justly and rightfully is and oweth to be the Supreme Head of the Church of England'. ${ }^{24}$

Considered in this light, John's speech to Pandulph is not merely a reiteration of Protestant propaganda in England under Elizabeth. Shakespeare has written a point-by-point restatement of the antipapal statutes of Henry VIII - and very nearly ticks through them in exact chronological order. By so doing, Shakespeare contrives to make his John thunder with the voice not of Elizabeth but of Henry 
VIII, father of Henry Carey. Elizabethans would not have confused the rhetoric of Henry VIII with that of Elizabeth as some scholars have done. Shakespeare's auditors knew that only Henry had been 'supreme head' of the English church; in 1559 Elizabeth became merely its 'supreme governor'. 25

\section{Carey and James Gournie}

In addition to time-shifting the on-stage action, Shakespeare sketched into King John an episode linking the Bastard with Henry Carey. He contrives for his Bastard to free the captured Queen Eleanor in 3.2, a feat performed by John in The Troublesome Reign; this is a nod at Carey's body-guarding Queen Elizabeth during the Armada scare.

Some other instances are particularly inscrutable; overt references to the newly deceased Carey in late 1596 could have run afoul of the censor. But as ephemeral as Shakespeare's Carey-Faulconbridge links may be, they are also unmistakable. The first appears when Eleanor recognizes Faulconbridge's resemblance to a deceased king, Richard Cordelion:

He hath a trick of Cordelions face,

The accent of his tongue affecteth him:

Do you not read some tokens of my sonne

In the large composition of this man? (1.1.85-8)

Henry Carey was said to strongly resemble Henry VIII in his face, brusque manner of speaking, and 'large composition', that is, burly physique. ${ }^{26}$ But this might have been said of any number of men.

Now comes one of Shakespeare's almost-invisible touches which link Faulconbridge with Carey: the name of Lady Faulconbridge's attendant, who does not appear in The Troublesome Reign but with whom Shakespeare's Bastard seems to enjoy familiar relations. The name appears as 'Gurney' in the Folio stage direction 'Enter Lady Faulconbridge and James Gurney' (1.1.219, stage direction). But the stage direction may have been a book-keeper's interpolation; Shakespeare spells the name 'Gournie' in the Bastard's speech, 'James Gournie, wilt thou give us leave a while?' (230).

As to the particularity Shakespeare lends to Gournie - who appears here and never again - Braunmuller notes that 'Shakespeare rarely names plebian characters so precisely unless there is an 
ulterior motive. ${ }^{27}$ Shakespeare's name, Gournie, points to France and Normandy, the ancestral home of the Careys. 'Gournie' is derived from the town of Gournay in Haute-Normandie not far from the Carreys' seat, Lisieux. ${ }^{28}$ Ascelin and Hugh de Gournay fought beside William the Conqueror at Hastings in 1066; perhaps some Carreys of Lisieux did, too. Shakespeare's wink at the Norman Gournay or Gournie is another nod to the Careys.

\section{Acts of recognition in King John}

The Troublesome Reign begins with Queen Elinor importuning the barons to recognize John as a worthy successor to late King Richard (1.1-8). When Shakespeare took up the old play he deftly restructured the drama to focus attention on acts of recognition; repeatedly, these occur at critical junctures.

Shakespeare's first act of recognition may have preceded his first line of dialogue; some commentators and directors believe that actus primus should open with a dumb-show coronation of John. ${ }^{29}$ I believe that Shakespeare's company offered a coronation pantomime preceding John's preemptory 'Now say Chatillion what would France with us?' (1.1.1, my emphasis). The coronation dumb-show may have been repeated prior to the first line of 4.2: 'Heere once againe we sit: once again crown'd'; John has been recognized as king a second time, much to the consternation of his nobles. In 5.1 John's kingship is recognized a third time as Pandulph replaces the crown upon his head. Against this repetitious, hollow pageantry Shakespeare sets the stony reality of the citizens of Angiers, who cannot and will not recognize John (or Philip of France) as their rightful king.

For his part, the Bastard is the focus of four acts of recognition. In 1.1 Eleanor recognizes Faulconbridge as the son of Richard Cordelion. In 5.1, the despairing John recognizes the Bastard as the leader of the English armies, saying, 'Have thou the ordering of this present time' (80). There is a final act of recognition in the play when the Bastard kneels before the boy-king Henry, saying, 'with all submission on my knee, I do bequeath my faithfull services And true subjection everlasting' (5.7.112-13). Shakespeare found all these acts of recognition in some form in The Troublesome Reign.

But Shakespeare added another act of recognition. It occurs in a scene which pre-echoes the opening of Hamlet. Both scenes take 
place in perfect darkness; the characters on stage cannot see one another's faces. King John 5.6 begins,

$H u b$. Whose there? Speak hoa, speak quickely, or I shoote.

Bast. A Friend. What art thou?

$H u b$. Of the part of England.

Bast. Whither doest thou go?

$H u b$. What's that to thee?

Hub. [Bas.] Why may not I demand of thine affaires, As well as thou of mine?

Bast. Hubert, I think.

Hub. Thou hast a perfect thought. (5.6.1-7)

The moment is an eerie pre-echo of the opening of Hamlet Q2:

Bar. Whose there?

Fran. Nay answere me. Stand and unfolde your selfe.

Bar. Long live the King.

Fran. Barnardo.

Bar. Hee. $(1.1 .1-4)^{30}$

In Hamlet, as in King John, a watchful soldier issues a challenge only to find himself challenged. In Hamlet the speakers recognize one another by voice. A few lines later the challenger in King John must ask, 'Who art thou?', to which the Bastard pregnantly replies, 'Who thou wilt; and if thou please Thou mayst befriend me so much as to think I come one way of the Plantagenets' (5.6.11-13, my emphasis).

Whereas The Troublesome Reign's acts of recognition were all matters of politics, Shakespeare's 5.6 has an elusive, almost existential quality. 'Who's there?' is the question of identity which haunts both Faulconbridge and Prince Hamlet. Shakespeare, commencing work on the revision that became Hamlet Q2, remembered his memorial for Henry Carey in King John. The common question tying the two protagonists is legitimacy and the right to rule - which links both Faulconbridge and Hamlet with the Careys. One might say that The Tragedie of Hamlet Prince of Denmarke begins at King John 5.6.1. (See 'On the illegitimacy of Hamlet' in 'Longer notes' below on Hamlet's questionable legitimacy.)

\section{Hamlet, Lamord, and the Careys}

When Shakespeare undertook the draft of Hamlet that we have in Q2, he devised a series of emblematic moments that remember and 
honour Henry Carey and son George. Elsewhere I have suggested that Hamlet Q2 is a revised text, purpose-written in mid-to-late $1603 .{ }^{31}$ I offered evidence that Q2 was a rewrite of a pre-existing, full-blown Hamlet, and proposed that Shakespeare's Q2 revision was occasioned by three events which occurred in 1603: the death of Queen Elizabeth during the night of 23-4 March 1603; the 'seven years' mind' of the death of Henry Carey in July 1596; and the death of George Carey on 9 September 1603.

A central element of Shakespeare's memorial for the Careys in Hamlet Q2 is the appearance in 4.7 of a mysterious Frenchman not present in the First Quarto (Q1). Suborning Laertes to Hamlet's murder, Claudius recalls:

some two months since

Heere was a gentleman of Normandy.

I have seene my selfe, and serv'd against, the French,

And they can well on horsebacke, but this gallant

Had witch-craft in't, he grew unto his seate ...

Laer. A Norman wast?

King. A Norman.

Laer.

King. Upon my life Lamord.

Laer. I know him well, he is the brooch indeed And Jem, of all the Nation. (Q2 4.769-82)

The intrustion of Shakespeare's mysterious Norman and the proper spelling of his name have eluded and tantalized scholars. Both mysteries can be solved by reference to a long-ignored incident that was a turning-point in the fortunes of the Carey family.

Henry Carey was the nominal son of William Carey, sometime Master of the Horse to Henry VIII, and Mary née Boleyn. ${ }^{32}$ The pair married on 4 February 1520; Mary was then fourteen, Carey twenty-four. Thereafter, Mary lived at court; her first child, Catherine, was born in 1524 - after which she embarked on an affair with the King for which her husband was richly compensated. ${ }^{33}$ Mary's royal tryst ended in July 1525 , perhaps when she realized she was pregnant by the King. On 4 March 1526 she gave birth to Henry Carey. Since it was common knowledge that King Henry had enjoyed Mary as well as her sister Anne ${ }^{34}$ - and since the boy Carey strongly resembled the King, and since the child was baptized Henry (as was the King's acknowledged bastard, Henry 
Fitzroy, 1519-37) - it was then as now suspected that Henry Carey was the King's bastard son.

But if Carey were Henry's natural son, why didn't he acknowledge him as he had Fitzroy, whom he created Duke of Richmond in 1524? Because had the King done so it would have raised a diriment impediment (his prior coitus with Mary) and rendered his marriage to her sister Anne void and their issue illegitimate. ${ }^{35}$ Even so, on William Carey's death (23 June 1528) the king seized two year-old Henry from his mother's care and appointed Queen Anne his guardian. ${ }^{36}$

Once at court the boy was well educated and popular. ${ }^{37}$ Henry became Elizabeth's favourite cousin; shortly after coming to the throne she created him Baron Hunsdon (1559) and Knight of the Garter (1561). She also named him Master of the Hawks. ${ }^{38}$ Carey patronized a company of players of which James Burbage was a member. Carpenter James was an impresario as well as an actor like his celebrated son; ${ }^{39}$ in 1584 he claimed to be 'Lord Hunsdon's man'. Shortly thereafter Elizabeth named Carey Lord Chamberlain. ${ }^{40}$

During his lifetime Carey seemed indifferent to the rumours about his birth and held himself out as a Carey and nothing but. His father, William (ca. 1500-28), was a descendant of an old Norman family; from Lisieux the Carreys had migrated to Guernsey and thence to England circa $1066 .^{41}$ But by the reign of Henry $\mathrm{V}$ the English Carys had apparently fallen on hard times. Then, suddenly, their line was ennobled by the remarkable feat of arms which was the defining event in the family's fortunes. The encounter is recorded in an obscure chronicle, Remarkable antiquities of the city of Exeter (1681). It is a tale uncannily parallel to Shakespeare's anecdote of Lamord:

[In] A.D. 1413 a Knight named Argonise, who in divers Countries for his Honour had performed many noble Achievements, at length visited England, and challenged many persons of his Rank and Quality to make trial of his skill in Arms, which the said Sir Robert Cary accepted, between whom was waged a cruel encounter and a long and doubtful combat in Smithfield, London; where this Mars vanquished this Argonise, for which he was by the King knighted and restored to part of his Father's inheritance. ${ }^{42}$

So William Carey's forebear Robert won his spurs and redeemed his family's fortunes by defeating a French champion at Smithfield 
under the eye of Henry $\mathrm{V}^{43}$ There is every reason to believe that the Careys of Shakespeare's era cherished the ancient victory; as the Exeter chronicler records, 'by the Law of Heraldry, whosoever fairly in the Field conquered his Adversary may fortify the wearing and bearing of his Arms ... and accordingly he [Sir Robert Cary] takes on him the Coat Armoury of the said Argonise, being Argent on a bend Sable, Three Roses of the First, and ever since borne by the name of Cary. ${ }^{44}$ As a consequence, the coat of arms of Argonise (Figure 8) was familiar to Elizabeth, her courtiers, and Shakespeare. It boldly adorns Carey's tomb in Westminster Abbey.

Having established the concordance between the historical Argonise and fictional Lamord, it may be possible to confirm the correct spelling of the Frenchman's name, a conundrum long debated. The difficulty arose from variants in Q2 and the Folio; whereas Q2 gives us Lamord, the Folio has Lamound - which latter spelling Rowe adopted in his edition of $1709 .{ }^{45}$ In 1725, Pope opted for Lamond. ${ }^{46}$ In 1821, Edmond Malone speculated that Shakespeare wrote 'Lamode' to suggest that the Frenchman was fashionable (à la mode). ${ }^{47}$ In the Victorian era 'Lamond' was preferred. ${ }^{48}$ Our contemporary editors embrace 'Lamord' unanimously,

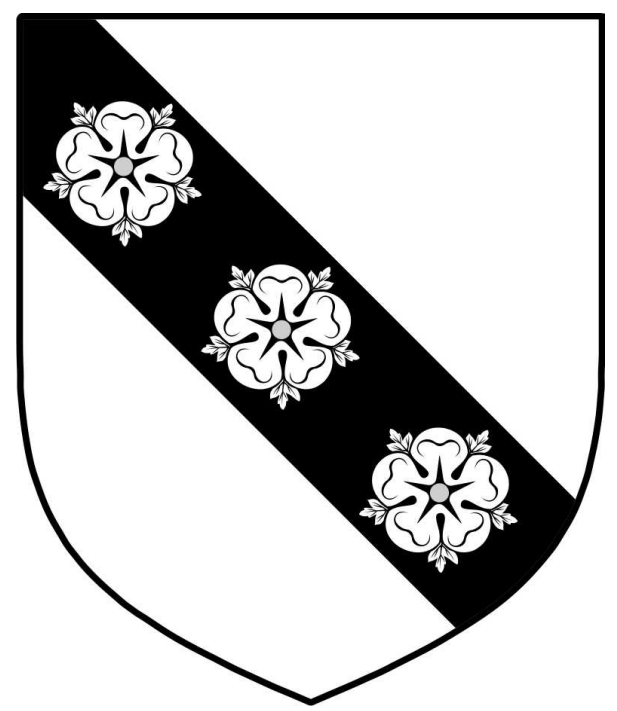

8 Coat of arms of Argonise and Carey 
beginning with Bevington (1988), and Wells and Taylor (1986).$^{49}$ In 2002 Orgel and Braunmuller footnoted with finality, 'Lamord i.e., "the death" (French: la mort)', which put period to the debate. ${ }^{50}$

But in 1899 Edward Dowden had produced a singular reading of Lamord: 'I retain the Q form of the name', he wrote, 'having noticed in Cotgrave, "Mords, [Fr.] a bitt of a horse." ${ }^{51}$ Jenkins, though unaware of the tale in the Exeter chronicle, also suspected a hidden significance: 'The excessively elaborate introduction of the fencing stratagem suggests ... it had for the dramatist some ulterior significance ... many suspect a personal allusion. ${ }^{52}$ In fact, Dowden and Jenkins came close to the truth; Lamord's identity is a personal allusion honouring the Careys, whose line was ennobled by the defeat of a French champion.

But if this is so, how is Shakespeare's fictitious name Lamord analogous to the name Argonise? Certainly, Shakespeare must have recognized that the historical champion's name implied he came from the wooded Argonne region of France. Does Shakespeare's fictitious Lamord also have a real world geographical etymology? I will suggest it does.

Dowden's curious reading was nearly correct; 'Lamord' derives from the French for the equine bitt or bit, mords. But the playwright's translation was not literal; rather, he is indulging in a typical Shakespearean wordplay - on the French mords = bite, and its homonym, 'byght' (modern: bight). A bight is an indentation in a coastline a body of water cupped between two headlands (OED), of which there are several in Europe, including the Egmont Bight in Dorset and the Helgoland Bight where the British claimed a famous victory over the German navy on 28 August 1914. Lamord's Norman background identifies his bight with the Seine Bight - that bay where the Seine empties into the Channel, hard by Harfleur, where Shakespeare's Henry V delivered his memorable 'Once more' exhortation to his reluctant English tigers. ${ }^{53}$ Argonise hailed from the Argonne region; Lamord from the Normandy's Seine Bight.

Among Norman towns south-east of the Seine Bight is Lisieux. ${ }^{54}$ The cathedral town was home to the Carrey family, whose namesake Henry was patron of Shakespeare's company and Lord Chamberlain. If this inference is valid, a defining event in Carey family history finally certifies the spelling of Shakespeare's Frenchman's name as Lamord - and not because it is fractured French for 'the death'. 


\section{Shakespeare's Onixe and Hunsdon's Onyx}

There is another passage unique to Hamlet Q2 which links Shakespeare's revision of his play to clan Carey. In the Folio, prior to the fencing match Claudius calls out,

Set me the Stopes of wine vpon that Table:

If Hamlet giue the first, or second hit,

Or quit in answer of the third exchange,

Let all the Battlements their Ordinance fire,

The King shal drinke to Hamlets better breath,

And in the Cup an vnion shal he throw

Richer then that, which foure successiue Kings

In Denmarkes Crowne haue worne ...

(Q2, throughlines 3727-34, my emphasis)

'Union' could mean 'marriage'. Or it could mean 'pearl'. Or it could mean both, which is marvellously apropos since pearls are known to dissolve in wine and Claudius's poisoned chalice will dissolve his marriage to Gertrude as it kills her; a husband's marriage to his wife ended at the moment of her death, a wife's marriage to her husband only once he was buried. The union-pearl in the cup is such an elegant metaphor that it's difficult to accept it as a later interpolation. ${ }^{55}$ Indeed, in Q2 it appears in a vestigial form which leaves no doubt that the metaphor was present in a version of Hamlet prior to 1604 (though not in Q1) and that Shakespeare altered it in his Q2 draft; I will suggest that he did so to honour the Careys.

In Q2 the object dropped into the chalice isn't a pearl; it is an 'Onixe'. Claudius says, 'And in the cup an Onixe shall he throwe' and, later, Hamlet says, 'Drink of this potion, is thy Onixe here?' As he worked up Q2 Shakespeare inserted 'Onixe' in the two places where the word 'union' had appeared in the pre-existing text.

But Shakespeare overlooked the single appearance in the old text of the word 'pearl'. After dropping an 'Onixe' into the cup Claudius says, 'Stay, give me drinke. Hamlet this pearl is thine' (my emphasis). Since the union-pearl metaphor doesn't appear in Q1, we must conclude that Q2 is a rewrite of a pre-1603 text which included a pearl but has been lost.

Which brings us to a pair of seemingly unanswerable questions. Having created his elegant union-pearl metaphor in an earlier draft of the play, why did Shakespeare disfigure it in the Q2 text? And why replace his union with, of all objects, an onyx? 
The answer to both questions can be seen today in a small glass display case in the Elizabethan gallery of London's Victoria and Albert Museum ${ }^{56}$ It is a fabulous and famous gem, the gift of Queen Elizabeth to a man who headed her bodyguard during the Spanish Armada emergency: her favourite cousin, Henry Carey. One can imagine how proudly Carey wore this magnificent tribute, perhaps hung about his neck on a heavy gold chain. The gem is known to historians of decorative art as 'the Hunsdon Onyx' (Figure 9). ${ }^{57}$

The jewel is an oriental sardonyx 3.75 inches high by 3.25 inches wide, the upper face white, the lower brown. It represents the myth of Perseus' rescue of Andromeda from imprisonment on an island. Sword in hand (left), Perseus descends from the clouds to her rescue. The piece is Italian, dated to the early sixteenth century, and in an English gold frame. Anyone spying this massive jewel on Carey's breast would recognize its portrayal of his defence of Elizabeth during the Armada emergency. For the multitude of courtiers who knew that George Carey (1547-1603) would have been King of England had Henry VIII married his grandmother instead of his great-aunt ... who remembered that the Careys fetched their coat-of arms from a French champion named Argonise ... and who had

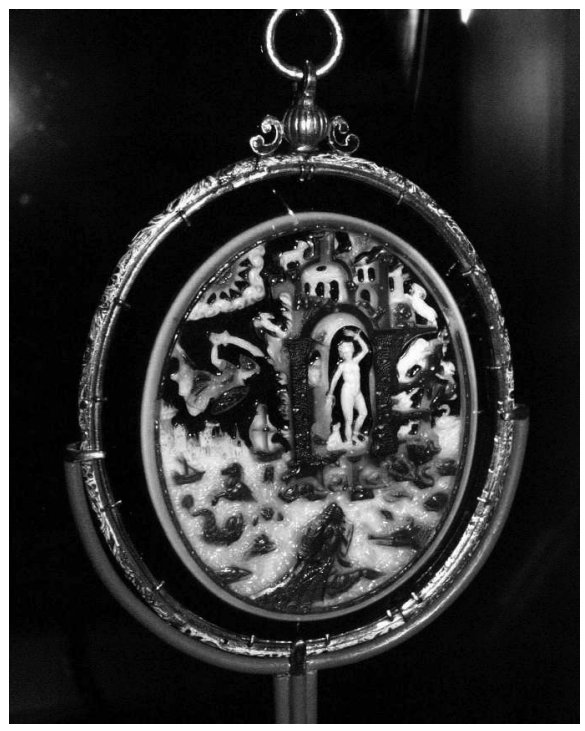

9 The Hunsdon Onyx 
seen Henry and George wearing the magnificent Hunsdon Onyx ... Shakespeare's previously unrecognized encomium in Hamlet Q2 rang clear.

\section{George Carey's last illness remembered}

Lamord and Claudius's Onixe would as readily connect Shakespeare's Danish prince with George Carey as with his father. But Shakespeare may have also included in Q2 a direct and trenchant reflection on George's final illness and death. Although the younger Carey died on 9 September 1603, he had relinquished the Chamberlain's white wand to Thomas Howard, later Earl of Suffolk, on 4 May. In fact, Howard had been discharging the office since 28 December 1602 because Carey was slowly dying of a sexually transmitted disease, most likely syphilis, and the effects of treatment with mercury.

Historians continue to debate whether syphilis was present in Europe in the medieval era or imported from the New World after 1492. By Shakespeare's time the malady the English called 'the French disease' was endemic; modern investigators speculate that syphilis carried off such luminaries as Henry VIII, Charles VIII, Francis I, and Ivan the Terrible. The madness of Henry's elder daughter, Mary, is ascribed to congenital infection and/or her contact with Philip of Spain. Since the disease felled heads of state and grandees as well as the poor, the progress of syphilis had been carefully observed by physicians and was well understood in Shakespeare's England.

Syphilis develops in four stages; the primary and secondary stages may run together during the first 90 to 120 days after infection. These stages are characterized by the appearance of sores and lesions, by fever and hair loss. Then, abruptly, the sufferer's symptoms vanish and the disease enters a latent, hidden phase. This hiatus may last a year or as many as twenty. The disease's emergence from latency - its tertiary stage - is marked by virulent symptoms which may include ulceration of the skin and internal organs, cardiovascular degeneration, intense thoracic pain - which the English called 'bone-ache' - and madness. Shakespeare may be glancing at George Carey's illness in a passage in Q2 which appears in neither Q1 nor the Folio:

There liues within the very flame of loue

A kind of weeke or snufe that will abate it, 
And nothing is at a like goodnes still,

For goodnes growing to a plurisie,

Dies in his owne too much, that we would doe

We should doe when we would: for this would changes,

And hath abatements and delayes as many,

As there are tongues, are hands, are accedents,

And then this should is like a spend thrifts sigh,

That hurts by easing; but to the quick of th'vlcer. (Q2 4.7.115-24)

This speech and its delicacy of phrasing seem wholly out of character as well as place; after all, evil usurper Claudius is suborning Laertes to Hamlet's murder. Shakespeare's catalogue of ills proceeding from 'the very flame of loue' includes pleurisy, death, sighs, hurts by easing, and ulcers; these could be symptomatic of any number of diseases. But they were symptoms of tertiary syphilis. Indeed, the reference to 'abatements and delayes' - with its sense of an opportunity missed - may refer to a syphilitic's latent stage. The Cambridge Hamlet editor, Philip Edwards, finds the disappearance of this passage from the Folio extraordinary. ${ }^{58}$ But it may have been a late interpolation; Shakespeare may have been in the midst of revising his play when news of George Carey's impending death arrived, which could explain its misfit tone. And discretion may have been the motive for Shakespeare's editors to delete it from the Folio text; Carey had then been dead for twenty years.

Though opaque to us until now, the composite portrait of Henry and George Carey in Hamlet must have been transparent to some of Shakespeare's first auditors, and conspicuously so to one important coterie: Carey's heirs and intimates. The Careys' long service as Lords Chamberlain may also explain why Hamlet takes upon himself so many of that officer's duties, for example engaging actors, choosing a play, vetting the argument, advising the players on decorum, even writing a dozen or sixteen lines.

What do Shakespeare's memorials for his deceased son and three Lords Chamberlain tell us about the playwright?

Recovering Shakespeare's tribute to William Brooke restores the paradigm of Henry Chettle's man of civil demeanour; we can recognize that Shakespeare's supposed slights to Brooke are susceptible of other, kinder explanations. Far from being snide or petty towards this Lord Chamberlain, Shakespeare composed for Brooke a tender memorial, one which may have been cherished by his heirs. 
To honour Henry Carey Shakespeare created one of his most dashing heroes - witty in speech, bold in action, royally magnanimous, loyal in life and to the death, and as humble and unselfish as Carey himself. Knowing that Henry Carey stands behind the flashing tongue and warlike arm of Philip Faulconbridge must deepen and excite anew our appreciation of the underappreciated King John.

And recognizing Henry and son George behind the mask of Hamlet brings new and tremendous pathos to the bastard prince's lament for the ineradicable stain on his soul. The only way a bastard could erase this stain would be to undo his birth. And that is the paradox that underlies the haunting question, 'To be or not to be ...'

\section{Notes}

1 Text and lineation from Gary Taylor, ed., Henry V, The Oxford Shakespeare (Oxford: Oxford University Press, 1982).

2 Oldcastle smuggled Wycliffite texts to the Continent, where they inspired Jan Hus and perhaps Martin Luther.

3 The interval between high and low tide is about 6 hours 12 minutes. But as tide-turn approaches the rate of rise or fall slows until it stops entirely and then slowly begins to move in the opposite direction. In the hours before and after high or low tide, the water level rises or falls by only a twelfth of its total.

4 The calendar of liturgical readings in the forepages of Elizabethan Bibles and Books of Common Prayer prescribed a specific clutch of Psalms to be read each morning and evening. By following this rubric Elizabethans would read or recite the entire cycle of 150 Psalms each month. In a thirty-day month the Twenty-Third Psalm was prescribed for evening prayer on the fourth day of the month. However, since February is a short month of only twenty-eight days, the order of the Psalms is altered during the three months of January, February, and March. The instruction in the Book of Common Prayer is as follows: 'And because January and March have one day above the said number [i.e. thirty-one days rather than thirty], and February which is placed between them both hath only twenty-eight days, February shall borrow of either of the months (of January and March) one day. And so the Psalter which shall be read in February must begin on the last day of January and end the first day of March.' In other words, those Psalms prescribed for the first day of a typical month were, for little February, advanced to 31 January. This caused the cycle of Psalms to run one day ahead throughout February; Psalms normally read on the second day 
of a month were recited on 1 February, and the Psalms for the twentyninth day of a typical thirty-day month were recited on 28 February. In leap years those Psalms were again recited on 29 February. The final clutch of Psalms in the cycle - those normally assigned to the thirtieth day of the month - were recited on 1 March. As a consequence, during March the Psalm cycle ran one day behind the calendar; those Psalms normally assigned to the first day of a thirty-day month were recited on the night of 2 March. Therefore, on the evening of 5 March, the Psalms were those for the fourth day of a normal thirty-day month, including the Twenty-Third Psalm.

5 Peter Alexander, Shakespeare's Henry VI and Richard III (Cambridge: Cambridge University Press, 1929), 201 ff; Ernst Honigmann, ed., The Life and Death of King John, The Arden Shakespeare, Series 2 (London: Methuen, 1963), xviii ff.

6 Ernst Honigmann, Shakespeare's Influence on his Contemporaries (Hong Kong: Macmillan, 1983), 56-90.

7 Eric Sams thinks Shakespeare wrote both. 'The Troublesome Wrangle over King John', Notes and Queries 234 (March 1988), 41-4.

8 Kenneth Muir, The Sources of Shakespeare's Plays (London: Methuen, 1977), 78-85.

9 For a fuller discussion see Steve Sohmer, Shakespeare for the Wiser Sort (Manchester: Manchester University Press, 2008), 145.

10 Oxford Dictionary of National Biography Online cites R. Naunton, Fragmenta regalia (1649), 102. In the original 'mistress', signifying Queen Elizabeth, stands in place of my 'monarch'. See Wallace T. MacCaffrey, 'Carey, Henry, first Baron Hunsdon (1526-1596)', Oxford Dictionary of National Biography, first published 2004; online edition, September 2014, www.oxforddnb.com/view/article/4649?docPos=15 (accessed 21 June 2012).

11 Calendar of State Papers Domestic, Addenda - Elizabeth, XVII.246, 26 February 1570, https://babel.hathitrust.org/cgi/pt?id=hvd.3204410649 0162; view=1up;seq=12 (accessed 21 June 2016).

12 MacCaffrey, 'Carey, Henry, first Baron Hunsdon'.

13 Of alabaster and marble, gilded, swarming with heraldry, and thirty-six feet tall.

14 Thomas Fuller, The History of the Worthies of England (London, 1662).

15 A. R. Braunmuller, ed., King John, The Oxford Shakespeare (Oxford: Oxford University Press, 1998), 92.

16 See for example Julia C. Van de Water, 'The Bastard in King John', Shakespeare Quarterly 11 (1960), 137-46, and Lily B. Campbell, Shakespeare's 'Histories': Mirrors of Elizabethan Policy (San Marino: The Huntington Library, 1947), 126-67. 
17 Sigurd Burckhardt, 'King John: The Ordering of this Present Time', English Literary History 33.2 (June 1966), 133.

18 Campbell, Histories, 166.

19 William H. Matchett, 'Richard's Divided Heritage in King John', Essays in Criticism 12 (July 1962), 2.

20 Citations from King John and throughline numbers from Charlton Hinman, ed., The First Folio of Shakespeare (New York: Norton, 1968), VII.323-44. Modern act and scene numbers from E. A. J. Honigmann, ed., King John (London: Methuen, 1954).

21 Another time-shift signal - one which is clear to scholars and could not have escaped the notice of Elizabethans familiar with The Troublesome Reign - is the absence from Shakespeare's King John of the Earl of Essex, an important figure in the earlier play.

22 Campbell, Histories, 154.

23 St Thomas More, Apology, xlv, in The Yale Edition of the Complete Works of St. Thomas More (New Haven: Yale University Press, 1979), IX.915.1.

24 Henry's acts can be found in Gerald Bray, ed., Documents of the English Reformation (Cambridge: James Clarke, 1994).

25 Braunmuller, King John, 178n.

26 According to MacCaffrey, 'Carey, Henry, first Baron Hunsdon', Carey 'stood out in the estimate of his contemporaries by his plain speaking, forthrightness, and lack of guile'. William Brooke's biographer, David McKeen, describes Carey as 'a bluff man and a good soldier ... unpolished'. McKeen, Memory, II.645.

27 Braunmuller, King John, 133n. Braunmuller speculates that the name may have been modelled after a Hugh [de] Gourney to whom Holinshed, a favourite Shakespeare source, refers elsewhere - which tends to support my inference. Holinshed also mentions the village Gornay in John's Normandy campaign of 1202. He writes that while the English succeeded in raising the French siege of Radepont, 'Howbeit after this the French king wan [won] Gourney'. Raphael Holinshed, Chronicles: England, Scotland and Ireland, 6 vols (London, 1807), VI.284.

28 W. Arthur, An Etymological Dictionary of Family and Christian Names, With an essay on their derivations and import (New York: Sheldon, Blakeman, 1857).

29 For example L. A. Beaurline, ed., King John, The New Cambridge Shakespeare (Cambridge: Cambridge University Press, 1990), 63n.

30 Moments later in Hamlet Q2, Horatio and Marcellus will enter and declare themselves 'Friend to this ground. And Leedgemen to the Dane' (1.1.12-13), echoing Hubert's 'Of the part of England'. There are more pre-echoes of Hamlet in King John. In both plays the death (murder) of a rightful king is compared with the first murder; Constance's 'For since 
the birth of Cain, the first male child, To him that did but yesterday suspire' (3.4.79-83) pre-echoes Claudius's 'From the first course [Abel], till he that died to day' (Q2 1.2.14-15). Young Prince Lewis's state of mind when he expresses his ennui, 'There's nothing in this world can make me joy. Life is as tedious as a twice-told tale ...' (3.4.107-11) is very like young Hamlet losing his mirth (2.2.306-15).

31 Sohmer, Wiser Sort, 127 ff.

32 One wonders whether Claudius' admiration for Lamord's horsemanship is a polite nod to the calling of Carey's nominal father, William, Master of the Horse for Henry VIII.

33 With manors, stewardships, and an annuity.

34 Reginald Pole reported that, in 1528, a member of Parliament accused Henry of sleeping Anne's mother as well as her sister. The flustered King replied, 'Never with her mother!' The anecdote is recounted in numerous sources. 'Mary Boleyn: Biography, Portrait, Facts \& Information', http:// englishhistory.net/tudor/citizens/mary-boleyn/ (accessed 22 March 2013).

35 The papal dispensation that Henry sought in 1527 to invalidate his marriage to Catherine was drafted by Cardinal Wolsey and intentionally framed in language so broad as to also sweep under the rug Henry's tryst with Mary. The document reads in part: 'In order to take away all occasion from evil doers, we do in the plenitude of our power hereby suspend ... all canons affecting impediments created by affinity rising ex illicito coitu, in any degree even in the first ... or of any affinity contracted in any degree even the first ...' Sir Gregory da Casale presented the petition to Pope Clement VII, who declined it; instead, he dispatched Cardinal Campeggio to England to join Wolsey in hearing the case between Henry and Catherine.

36 Mary's subsequent marriage to commoner William Stafford (1534) estranged her from her ambitious family and royal in-laws; she descended into poverty and died (19 July 1543) dependent on the kindness of strangers.

37 His tutor was Nicholas Bourbon, the French poet and Latin doggerel writer; Hamlet, of course, fancies himself poetical.

38 Which may have put those 'hawkes and handsaws' into Shakespeare's mind in Hamlet 2.2.397.

$39 \mathrm{He}$ is named among the list of the Earl of Leicester's players in a document of 7 May 1574.

40 The Carey family had close ties to other members of Shakespeare's circle. George Carey's wife and daughter, both named Elizabeth, were patrons of writers including Edmund Spenser and Nashe. George's daughter and heiress, Elizabeth, married Sir Thomas Berkeley, son and heir of Henry, Lord Berkeley. 
41 They amassed land and influence, and are numerous today. In Normanville, La Courture, Guernsey, there stands an imposing house which, according to the Livre de Perchage, was owned in 1573 by Jean de Vic, husband of Anne Careye [sic]. See 'The History of the Carey Family of Guernsey A.D. 1393-2008', www.careyroots.com (accessed April 2012).

42 By AD 1085 there were four branches of Careys in Somerset and Devonshire. See ibid. The original Carey arms had been 'Gules, a chevron between three swans proper, one thereof they still retain in their crest'. Richard Izacke, Remarkable antiquities of the city of Exeter, collected by Richard Isacke, Esquire, Chamberlain thereof (London, 1681), 71.

43 Carey named a younger son Robert.

44 Izacke, Remarkable antiquities, 72. In "The History of the Carey Family of Guernsey', Paul Dobree-Carey records that 'The arms were first noted in Guernsey in documents borne by Nicolas Careye as Lieutenant of Thomas Wygmore, Bailiff of Guernsey, dated 1582 ... the arms for the English branch having been registered by the Heralds College in 1531.'

45 Nicholas Rowe, ed., The Works of Mr William Shakespear (London, 1709), V.245.

46 Alexander Pope, ed., The Works of Shakespear, 6 vols (London, 1725), VI.446.

47 Citing 'the next speech but one: "he is the brooch, indeed, And gem of all the nation". Edmond Malone, ed., The Plays and Poems of William Shakespeare, 10 vols (London, 1821), VII.452.

48 By J. P. Collier (1858), Dyce (1877), Wright (1894), Verity (1911), and Brook's and Crawford's Yale (1917). Only Craig (1905) held out for Lamord. 'This name, so suggestive of La Mort, looks the right name for the centaur-like Norman conjured up out of nowhere [and] Lamound seems more like to be a misreading of it ...' G. R. Hibbard, ed., Hamlet, reprint, The Oxford Shakespeare (Oxford: Oxford University Press, 2008), 315n.

49 See David Bevington and David Scott Kasdan, eds, The Tragedy of Hamlet, Prince of Denmark (New York: Penguin, 1988); Stanley Wells, Gary Taylor, John Jowett and William Montgomery, eds, The Oxford Shakespeare: The Complete Works (Oxford: Oxford University Press, 1986).

50 Stephen Orgel and A. R. Braunmuller eds, The Complete Pelican Shakespeare, 2nd revised edition (New York: Penguin, 2002).

51 E. Dowden, The Plays of Shakespeare (London, 1899), VI.179. He did, however, perceive that his proposed emendation - 'Lamords' - would be agrammatical since 'the word mords is masculine'. He attributed this 
to printing-house error: 'the printer of $\mathrm{Q}$ may be responsible for $L a$, the feminine article instead of a masculine $L e$.

52 Harold Jenkins, ed., Hamlet, The Arden Shakespeare, Series 2 (London: Methuen, 1982), 369n.

53 Henry V 3.1.1-34.

54 Le Manoir Carrey still stands in the town, the present structure being a sixteenth-century half-timbered, three-storey dwelling.

55 Consider Hamlet's cry in Q1, 'Then venom to thy union here' as he stabs Claudius.

56 Thanks to Lucy Cullen of the Department of Sculpture, Metalwork, Ceramics and Glass, Victoria and Albert Museum.

57 'The celebrated Hunsdon onyx cameo, set in an enameled gold pendant illustrates marvelously the virtuoso talents of one of the best - albeit anonymous - hardstone engravers of the Renaissance ... [and] matches the best engraving of the great cameo-cutters of ancient Greece and Rome.' Diana Scarisbrick, Ancestral Jewels (New York: Vendome Press, 1989), 15.

58 Philip Edwards, ed., Hamlet, The New Cambridge Shakespeare (Cambridge: Cambridge University Press, 1985), 209n. 